should learn from bacteria, the diversity of whose accomplishments take over a page to list, declaring finally:

'So in the tired game of identity, I would choose neither goddess nor cyborg (Haraway 1991). I would rather be a bacterium'

By the end of the book, I couldn't have agreed more.

doi: $10.1057 /$ palgrave.fr. 9400290

Karen Throsby

\title{
Some of us: Chinese women growing up in the Mao era
}

Xueping Zhong, Wang Zheng and Bai Di (editors); Rutgers University Press, New Brunswick, New Jersey, and London, 2001, 224p, ISBN 0-8135-2969-7 $£ 15.50$ (Pbk); ISBN 0-8135-2968-9£40.50 ( Hbk)

At last, Anglophone readers have an alternative to the stereotypes of suffering and persecution that dominate the numerous autobiographical accounts of the Mao years. Mao's rule involved crimes on a scale and of an order that have still not been properly accounted for. The experience of many who grew up under Mao's 'red banner', including those contributing to this volume, does not deny this, but it suggests a much more complex history than the accepted narratives of the 'victim' genre offer.

Some of Us is a collection of nine memoirs written by Chinese women, mostly from privileged urban families and now working as academics in the United States. Some were members of Mao's 'sent down youth', whose adolescent years were spent thousands of miles away from home in distant villages and state farms. Often left at home to fend for themselves during years when their parents were sent away to undergo political training in 'cadre schools' during the Cultural Revolution, they tell of the delights and difficulties of dealing with the independence that political circumstance gave them. The bare 'facts' of their adolescent experiences are not too different from many of those who have written the familiar mainstream accounts. Yet wanting to account for their past from their detached position in the States, they offer an appreciation of the powerful effects of the Mao era in shaping their cultural and personal identities. In their memories of their adolescent dreams, of their rebellions against their parents, and their own emerging and powerful sense of self formed through the opportunities and limitations that these years represented, the volume thus gives us fresh perspectives on how and why young people of the time 'bought into' Mao's project of social transformation. 
Reflections on the changing discursive meanings of gender, and the intersection between these and the contributors' formation of self is another prominent theme in this collection. Many of the contributors first came across the notion of gender as a critical category when they arrived as students in the United States. Armed with the critical insights offered by feminist theory, they could then revisit their experience of the Cultural Revolution's rhetoric and practice of 'sexual equality' to reflect on the particular influence it had exerted on their own maturation as gendered subjects. A number of the contributors describe their disdain of the subject positions associated with the discursive terms used at the time for 'woman' and 'housewife'. They describe the self-confidence that young women could acquire through self-identification as gender-neutral revolutionary 'youth' (qingnian). The notion of 'youth' of the Mao years had few explicit gender connotations, and the youthful (qingnian) ideal of equality was infused with the political commitments which seemed to transcend gender difference. However, thinking back, Wang Zheng suggests that the 'gender-neutral' rhetoric of these years was by no means devoid of gender meanings. It did not signify a notion of 'liberation' along the lines of the second wave of feminism in the West, but it did, 'demonstrate the party's attempts to situate citizens in a new kind of social relationship, to.... redirect their ethical duties from their kin to the party and the nation.' While many might condemn this as the social engineering project of a state bent on social domination, few, Wang Zheng suggests, have commented that 'the enforcement of this scheme disrupted conventional gender norms and created a new discursive space that allowed a cohort of young women to grow up without being always conscious of their gender' (p. 52).

Recognition of the importance of difference in conceptualizing social and gender practice emerges as a powerful, if implicit theme. It also emerges as a powerful inspiration to the feminist commitments shared by the contributors to this volume. Naihua Zhang recalls the close friendships with rural women established during her years working on a farm in the distant north-east. She describes her sense of betrayal of the dreams they shared when she returned to the city to enter higher education, leaving them to a future of economic and cultural constraints. Her acknowledgment of the tensions between her own privileged position and the disadvantanged status of the women with whom she worked established an understanding of gender difference that had a formative influence on her personal development as a feminist. Similarly, Xiaomei Chen, the daughter of 'luminaries of the theatre' describes the sense of empathy she developed for people from very different backgrounds she met when working in a state farm in the early 1970s. The youthful ideals of equality and justice she developed in those years found a new form in her later commitment to exploring the possibilities of critical feminist theory as an academic.

Many other reflections on the meanings of gender and generation in the formation of self arise in this volume. The shifting boundaries between constructions of the 
female and the domestic and public spheres; the effects on personal development of an enforced - though often welcome - independence during adolescence; intense and difficult relationships with mothers who represented models of the gender equality of the time but who were not around to care for their children. Participating in street drama troupes, leaving home to go on revolutionary 'long marches' alongside millions of other teenagers, or organizing experimental agricultural techniques in the cold north-east - through these different recollections, the contributors create a powerful sense of the autonomy they acquired as children and teenagers that informed their personal and professional choices in adult life. These are extraordinary women, who whatever our 'outsiders' interpretations of their revolutionary pasts, have moulded their experiences of growing up during an extraordinary time into their feminist takes on their own presents. All acknowledge the enriching insights into their pasts that their positions of detachment as academics in the US offer. Detachment across time and place may also explain the nostalgic tones of many of these accounts. But as the editors of Some of Us: Chinese Women Growing Up in the Mao Era note, experience and memory are 'sites of struggle for historical representations and experiences.' The issue is not to acknowledge experience as 'historical truth', but to recognize their historicity, and therefore importance in contributing, alongside others, to a comprehensive analysis of historical processes.

doi:10.1057/palgrave.fr.9400291

Harriet Evans

\section{Behind closed doors: domestic violence in India}

Rinki Bhattacharya (editor); Sage Publications, New Delhi/Thousand Oaks/London, 2004, 234p; ISBN 0-7619-3239-9 £14.99 (Pbk); ISBN 0-7619-3238-0£29.99 (Hbk)

Domestic violence is the most serious violation of all basic rights that a woman suffers in her own home at the hands of members within her own family. The manifold problems associated with domestic violence have been systematically exposed by data and in-depth work has been undertaken by several people in the women's movement. The few studies available indicate that physical abuse of Indian women is quite high, ranging from 22 to 60 per cent of women surveyed (Mahajan, 1990; Rao, 1997). Most of the available information consists of qualitative studies of very small sample size. The only large-scale indicator of violence against women is the data relating to crimes against women published by the National Crimes Record Bureau, Ministry of Home Affairs, Government of India. The records of the bureau reveal a shocking 71.5 per cent increase in cases of torture and dowry deaths during the period from 1991 to 1995 and may reflect increased reporting of violence. 